\title{
Snow loads in a changing climate: new risks?
}

\author{
U. Strasser \\ Department of Geography, Ludwig-Maximilians University (LMU), Luisenstr. 37, 80333 Munich, Germany
}

Received: 19 September 2007 - Revised: 20 November 2007 - Accepted: 6 December 2007 - Published: 9 January 2008

\begin{abstract}
In January/February 2006, heavy snowfalls in Bavaria (Germany) lead to a series of infrastructural damage of catastrophic nature. Since on many collapsed roofs the total snow load was not exceptional, serious engineering deficiencies in roof construction and a sudden rise in the total snow load were considered to be the trigger of the events. An analysis of the then meteorological conditions reveals, that the early winter of 2005/2006 was characterised by an exceptional continuous snow cover, temperatures remained around the freezing point and no significant snowmelt was evident. The frequent freezing/thawing cycles were followed by a general compaction of the snow load. This resulted in a re-distribution and a new concentration of the snow load on specific locations on roofs. With respect to climate change, the question arises as to whether the risks relating to snow loads will increase. The future probability of a continuous snow cover occurrence with frequent freezing/thawing cycles will probably decline due to predicted higher temperatures. However, where temperatures remain low, an increase in winter precipitation will result in increased snow loads. Furthermore, the variability of extremes is predicted to increase. If heavy snowfall events are more frequent, the risk of a trigger event will likely increase. Finally, an attempt will be made here in this paper to outline a concept for an operational warning system for the Bavarian region. This system envisages to predict the development and risk of critical snow loads for a 3-day time period, utilising a combination of climate and snow modelling data and using this together with a snow pillow device (located on roofs) and the results of which.
\end{abstract}

Correspondence to: U. Strasser

(u.strasser@iggf.geo.uni-muenchen.de)

\section{Introduction}

Widespread parts of Bavaria were severely effected by heavy snow in the early winter 2005/2006. The early winter season was characterised by an exceptionally high and continuous snow cover, temperatures recorded remained around the freezing point and typical intermediate warmer periods with partial or complete snow cover thaw lacked completely. In the first week of 2006, all local and national headlines focused on the tragic event which happened in Bad Reichenhall. On 2 January 2006, the roof of the ice rink collapsed killing 15 people and injuring 34 . Up until the end of February, a series of snow load damage related cases involving buildings and infrastructure were reported. In most cases, the snow loads reported on the roof structures were not exceptionally high. The media tackled the theme in arousing discussion asking the question whether the situation was to be attributed to an effect of climate change and furthermore asking if such situations could occur more frequently or more disastrously in the future. In January 2007, the Versicherungskammer Bayern (http://www.versicherungskammer-bayern.de) organized a national symposium dealing with this issue bringing together experts from science, engineering and politics.

In this paper, an attempt is made to review the outcome of what has been discussed and agreed upon in this particular symposium with respect to snow loads on roofs, the meteorological conditions of that particular winter of 2005/2006 and potential effects of climate change. Furthermore, the structure and design of a warning system capable of predicting critical snow loads will likewise be discussed.

Many erroneous opinions are common in the public sector when it comes to the terms and units associated with snow loads. In this paper, an initial step clarifies the relevant terms. What is apparently visible after a snowfall is what is known as the snow depth. A $1 \mathrm{~m}$ high snow pack can have major consequence be it in a positive sense (e.g. for a ski

Published by Copernicus Publications on behalf of the European Geosciences Union. 


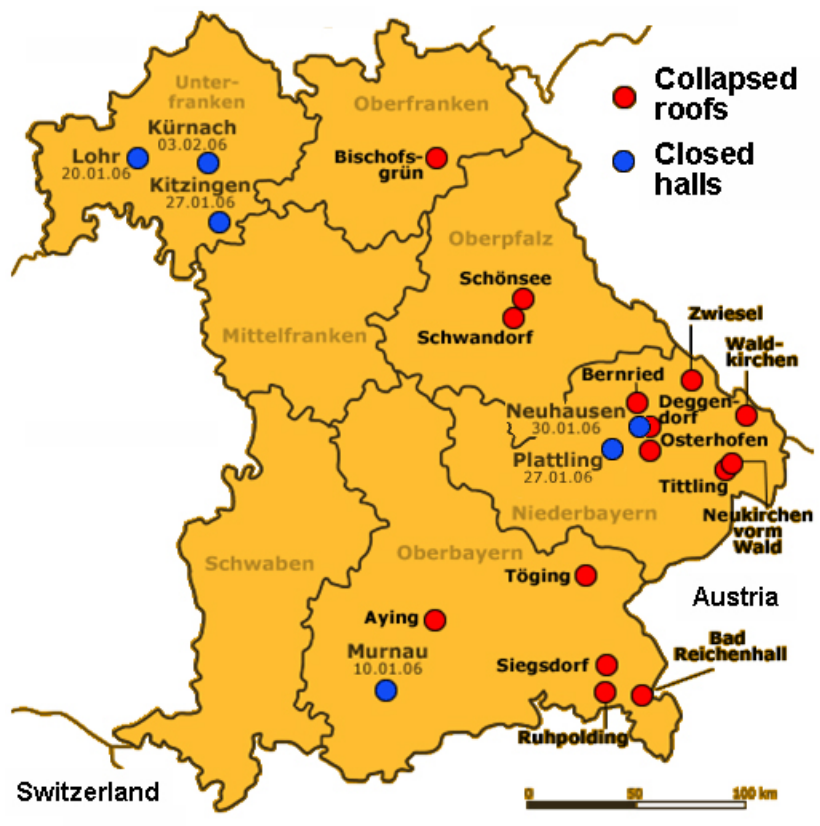

Fig. 1. Collapsed roofs and site closures in Bavaria during the period January/February 2006. Modified after http://www.br-online. de/topthema/thema/schnee-chaos/index.xml.

resort) or in a negative sense (e.g. for road traffic). However, snow depth alone does not determine the mass. Depending on the density of the snow, snow mass can be distinctly different. Density is mass per volume with unit $\mathrm{kg}_{\text {per }} \mathrm{m}^{3}$. The density of fresh, light snow is approx. $100 \mathrm{~kg} / \mathrm{m}^{3}$, very wet snow is approx. $500 \mathrm{~kg} / \mathrm{m}^{3}$ and ice weighs $900 \mathrm{~kg} / \mathrm{m}^{3}$ (Maidment, 1993). Consequently, a $12 \mathrm{~cm}$ thick ice layer of $1 \mathrm{~m}^{2}$ is heavier $(108 \mathrm{~kg})$ than a $1 \mathrm{~m}$ fresh snow pack of the same size $(100 \mathrm{~kg})$. However, neither snow depth nor snow density, which can widely vary between the layers of a snow pack alone, is relevant for the correct definition for the snow load. The snow load is its mass synonymic with the snow water equivalent (swe), unit $\mathrm{kg}$ per $\mathrm{m}^{2}$ or $\mathrm{mm}$, mathematically identified as the product of snow depth and snow density. The snow water equivalent corresponds to the height of the water table if all snow on a certain area melts. These relations have often been pointed out erroneously in the media after the snow load related events of January and February 2006. If no melt water drains from a melting snowpack on a roof, snow depth decreases, density increases, but the overall load remains exactly constant, even so when the water refreezes. Potential sublimation is neglected here. The so-called "glacier effect", i.e. the compaction and thawing/refreezing of the lower layers of a snow cover and its respective increase in density is of minor importance for the snow load, since the total mass of the snow pack is not effected. Nevertheless, the drainage system on a flat roof may well be effected if water refreezes. The only possibility to increase the overall snow load on a roof is by additional pre- cipitation and again, it is the snow water equivalent related to precipitation which plays the critical role here and not whether if precipitation falls as heavy or light snow or rain.

\subsection{Collapsed roofs in January and February 2006}

The Bad Reichenhall incident of 2 January 2006 was the first of its kind in the series of roof collapsing incidents located in Bavaria. Figure 1 shows the locations where similar structural damage occurred within this period January, February 2006. Structural damage occurred on 3 January in a hall in Aying, on 22 January in a riding hall in Deggendorf, on 7 February in a supermarket in Töging, on 10 February in another riding hall in Zell/Ruhpolding and so on. In all cases, the roofs gave in and collapsed. Local Bavarian mayors ordered respective communities to prohibit admission to buildings with flat roofs as they posed a great risk at this particular time. The incident at Bad Reichenhall was the only one of its kind in Bavaria where human lives were lost. Similarly on 28 January 2006, the roof of an exhibition hall in Kattowitz/Poland collapsed after heavy snowfall burying 235 people of which 65 perished.

Astonishingly, it was observed that in neither of the disasters was the snow depth on the roof exceptional. In Bad Reichenhall, the media recorded a snow load of $30 \mathrm{~cm}$. According to observations by the German Weather Service (DWD), the total winter precipitation was well below average (Müller-Westermeier, 2006). As a consequence, discussions arose among the structural designers, architects, construction supervisors and building authorities of the municipal administrations and acquisitions were publically made regarding the question of responsibility and blame behind the collapse.

It is a simple fact that the cause for the structural weakness in the aforementioned cases was that the construction's local stress was higher than its local stability, with risk being defined as the product of expected damage and its probability.

\subsection{Snow loads and DIN 1055-5}

The snow load on a roof is equal to the ground snow water equivalent under the assumption that not only is a roof completely sheltered from the wind but there is no thawing process involved. Under calm conditions, falling snow will cover the roof and ground with the same uniform layer. This will in turn grow in depth with each successive fall provided that the temperature of the air and the roofs surface remain below the freezing point. The estimation of the snow load on roofs is then a relatively simple matter totalling the ground snow water equivalent. However, such calm conditions are rare and occur only in sheltered locations. In reality, the average snow load on roofs is lower than the snow water equivalent on the ground.

In Germany, each building is assigned with a certain roofspecific designated snow load threshold, regulated by the German Industry Norm (DIN) 1055-5 (DIN, 2005). This 


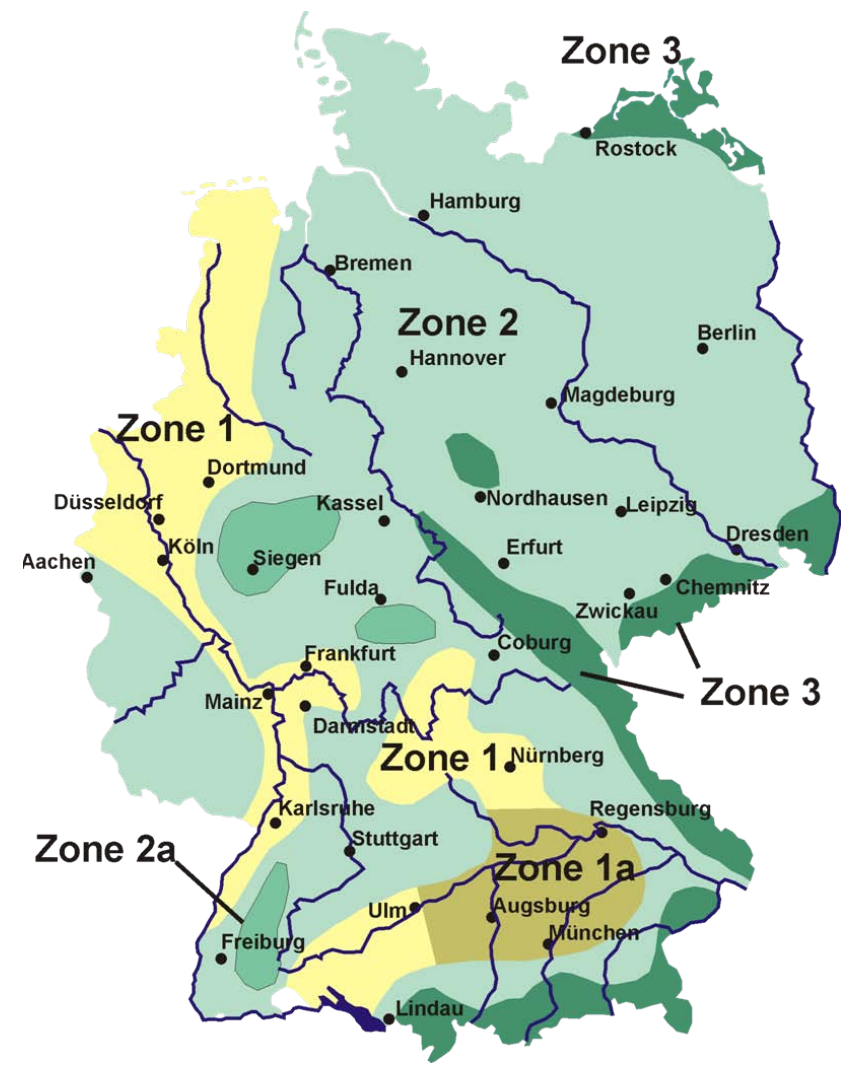

Fig. 2. Snow load zones in Germany. Modified after DIN 1055-5.

designated snow load threshold reflects a combination of the following factors: geographical location, topographical altitude above sea level and the roof's pitch. To determine the effect of the geographical location, the German state has been divided into so-called snow load zones, reflecting the spatial heterogeneity of snowfall precipitation and its effect on the spatial distribution of the ground swe (Fig. 2). The five evolving snow load zones were based on 50-year reoccurrence measurements of the swe based on the location of meteorological stations. In a further step, the topographical altitude above sea level is taken into account as is depicted in the diagram illustrated in Fig. 3. For example, the snow load of a location based in zone 3 at $500 \mathrm{~m}$ a.s.1. amounts to approx. $2.4 \mathrm{kN} / \mathrm{m}^{2}$ or $240 \mathrm{~kg} / \mathrm{m}^{2}$. This load is then multiplied with a form factor to account for the roof's pitch specific for certain buildings (Fig. 4). The form factor considers the fraction of snow on the roof to the precipitation which has fallen, thus accounting for the fact that the snow load decreases as the roof slope increases. This is mainly because the steeper a roof is, the greater the chance that some of the snow will slide off. Neglecting thawing or sublimation processes, 0.8 is the assumed reduction factor for the average difference in mass between ground snow and the snow on a roof. Accordingly, the designated snow load threshold for a building with a flat roof in zone 3 at $500 \mathrm{~m}$ a.s.l. amounts to

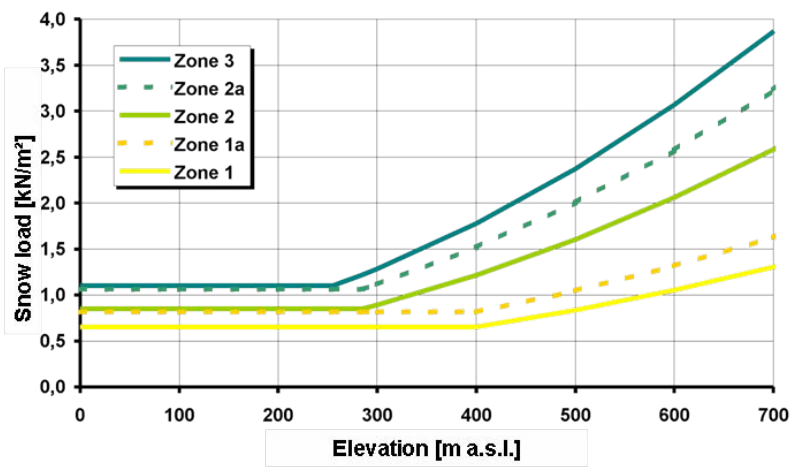

Fig. 3. Snow load and relationship to elevation for different snow load zones. Modified after DIN 1055-5.

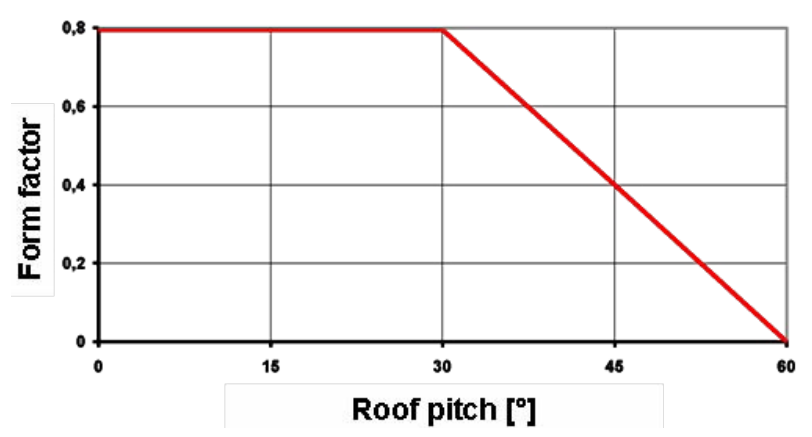

Fig. 4. Form factor to derive the snow load for a roof's pitch. Modified after DIN 1055-5. The resulting load is the designated snow load specific for a sheltered roof.

$192 \mathrm{~kg} / \mathrm{m}^{2}$. If one assumes a very dense snow $\left(500 \mathrm{~kg} / \mathrm{m}^{3}\right)$, the designated snow load threshold in this example equals a snow depth of max. $38.4 \mathrm{~cm}$. In February and March 2006, when the amount of heavy snowfalls increased, the actual snow loads in some parts of Bavaria totaled such critical values. The result, snow had to be removed from the roofs of many buildings. Thousands of volunteers, fire department staff, mountain rescue services and even military units joined together clearing many roofs of snow.

The question however arises as to why some structures were in the position of possibly collapsing at a time when the actual snow load was apparently below the critical designated snow load threshold. The total accumulated precipitation in mean altitudes in east Bavaria amounted to $155 \mathrm{~mm}$, with a respective potential snow load of $155 \mathrm{~kg} / \mathrm{m}^{2}$ (MüllerWestermeier, 2006). Yet, many structures seem to have resisted higher snow loads before this taking for example the years 1999 or 2005. Taking these two statements into account, the facts suggest that the meteorological conditions and the development of the snow cover may have indeed been extraordinary in early winter of 2005/2006. 


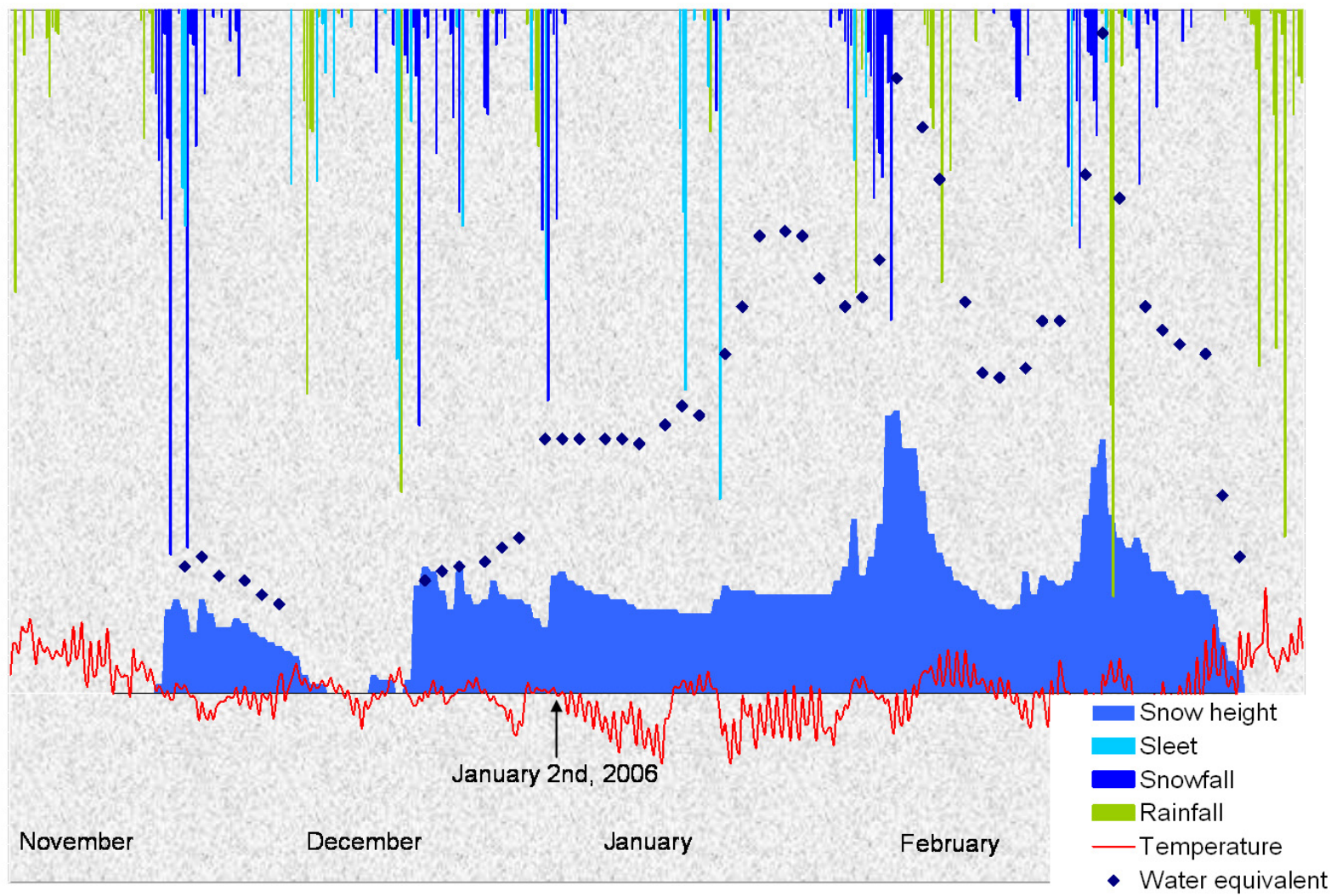

Fig. 5. Recordings of meteorological variables and ground snow cover from November 2005 to March 2006 at the DWD met office station Bad Reichenhall.

1.3 The development of the meteorological conditions 2005/2006

The meteorological and the snowpack conditions which developed in the early winter of 2005/2006 thereby effecting Bad Reichenhall have since been evaluated and analysed. A German met office (DWD) station is located near to the particular ice rink which collapsed in Bad Reichenhall $\left(47^{\circ} 43^{\prime} \mathrm{N} 12^{\circ} 53^{\prime} \mathrm{E}, 470 \mathrm{~m}\right.$ a.s.1.). The recordings of this station comprise of both snow depth and swe (DWD, 2006). The recorded measurements are illustrated in Fig. 5. Meteorological observations were obtained 3 times daily at the Mannheimer Stunden (07:30, 14:30, 21:30 Central European Time CET) and the swe was recorded every second day. First snowfalls started in the second half of November. This initial snow cover remained until the end of March and this period was interrupted in mid December by a short snow-free period, characterised by heavy rainfall and warm temperatures. It is unclear whether the melt-out is specific for the location of the station, or also occurred on the roofs in the vicinity. More importantly is the fact, that this phase was followed by a period of frost and subsequent snowfalls. It is particularly evident that temperatures rallied around the freezing point during the entire period between the end of
November through to the beginning of January. Hence, local re-distribution of the snow load on a roof may well have occurred as a result of thawing and subsequent refreezing phases. Even with air temperatures below freezing, thawing can still occur due to a loss of heat through the roof itself or by warmth or heat generated and released by air conditioning or ventilation funnels. This in turn can lead to additional loads in those locations on a roof where melt water collects and refreezes. On flat roofs in particular, this can occur in areas where the roof has sections which are greatly uneven i.e. at the mid-span of roof beams. On sloping roofs, melt water often refreezes along the eaves.

On the day of the incident in Bad Reichenhall, the DWD met station recorded a snow depth of $26 \mathrm{~cm}$ and a corresponding swe of $54 \mathrm{~mm}$. In general, the maximum snow mass cannot exceed total precipitation from the time of the first snow falls in November. The accumulated precipitation at this station in Bad Reichenhall amounted to $66 \mathrm{~mm}$. An excess of $12 \mathrm{~mm}$ must have drained, sublimated or must have otherwise been removed from the observed ground snow, for example by means of wind-induced erosion. Any potential maximum mass of the load on the roofs in the vicinity should not exceed $66 \mathrm{~kg} / \mathrm{m}^{2}$. An accumulation of more snow can only be locally achieved by means of wind-induced 
deposition of snow, i.e. on flat roofs with walls around which act like a snow catch.

The specific course of the meteorological conditions and respective snowpack development in the early winter of $2005 / 2006$ may play a key role in understanding why so many structures could not stand the moderate snow loads. This course of events is evidently more unique than the actual total load on the roofs during that period (MüllerWestermeier, 2006). An analysis of the recordings of other DWD met stations situated in the disaster area reveal that not only was a near to continuous snow coverage since mid November evident but a frequent interaction between freezing and thawing was widely observed e.g., Holzkirchen, Mühldorf/Inn, Fürstenzell (DWD, 2006). Hencewith, many construction structures were potentially effected by the redistribution and the local increase of the snow load. This particular cycle repeated itself several times lacking however an intermediate drying process. On the day of the accident in Bad Reichenhall, a significant rise of the overall load on the roof of the ice rink was the result of a heavy precipitation event involving first rain, then sleet and later snow, i.e. temperatures dropping below the freezing point (refer to Fig. 5). Hence, the continuous snow coverage, continuous freezing/thawing phases and a lack of warm drying periods characterise the meteorological conditions which may have re-distributed the snow load on the roof as a result of accumulation and subsequent refreezing of melt water in sections of a roof where the roof's unevenness was greatest. The element wind may additionally have triggered local re-distribution of snow, yet the effect is roof-specific and regional generalisations cannot be made. Thereby, the rapid increase of the local accumulation of the snow load on such uneven sections of roofs as a result of a heavy precipitation event involving refreezing and may well have been the ultimate trigger responsible for the roof collapse.

As the construction objects were destroyed in their entirety, it was not possible to analyse and measure the snow load accumulation deposited in uneven sectors of roofs. This phenomenon is quite common in areas of risk management analysis.

\subsection{Climate change, snow load related risks?}

Future climate change is generally predicted by the application of global circulation models (GCM's) with a variety of nesting and downscaling techniques transferring the simulation results to the considered (smaller) scale. A set of scenarios defining future evolution key factors determining the processes simulated by the GCM's have been elaborated by the Intergovernmental Panel on Climate Change (IPCC, 2008). These scenarios are used as general set-ups for the various GCM runs. Consequently, a variety of future climate predictions exist depending on which model and scenario combination has been used in the simulation. The interpretation of the results is complicated due to the fact that the spatial res- olution of downscaled climate predictions is typically much coarser than the scale of a specific location. In terms of predictability, it should be kept in mind, that the collapse of a structure or roof cannot necessarily be attributed to a single meteorological event where the snow load exceeds a critical value. From what has already been outlined in this paper, it should become apparent that the snow load related risk is the result of a complex interaction of several factors and thereby probably impossible to accurately predict, in particular at scales larger than a single building. Nevertheless, an attempt shall be made here to evaluate the potential future development of the subset of climate related factors.

From an abundance of available climate simulations, a so called "Regionalmodell" (REMO) A1B simulation has been selected as a good example applicable for the German region with a 100-year scenario period (MPI, 2007). The expected relative changes of mean winter temperatures and precipitation are illustrated in Fig. 6. Simulated changes show a small-scale pattern mostly visible in the precipitation image. Taking the Bavarian region into consideration, an increase in mean winter temperature of approximately $4^{\circ} \mathrm{C}$ can be deduced accompanied by a spatial varying increase of the mean winter precipitation of up to $25 \%$.

The potential consequences associated with the risk pertaining to the snow load can be summarised as follows:

- An increase in mean temperatures will result in less snowfall and an increase in rainfall

- The effects of atmospheric warming will result in the reduction of long periods with continuous snow coverage in lower regions

- When rain falls on an existing snow cover, the rain may be stored there leading to an increase of the respective snow load. Consequently, less snowfall does not necessarily implicate less snow load

- As a result of an increase in precipitation, more snowfall must be expected in areas where it is still cold enough for precipitation to fall in its solid phase, i.e. higher mountainous regions. Snowfall events typically occur between $-4^{\circ} \mathrm{C}$ and $+3^{\circ} \mathrm{C}$.

- A predicted increase in the variability and probability of meteorological extremes may result in more frequent heavy snowfall events

The aforementioned points generate a complex pattern indicating the possibility of more risk associated with critical snow loads and of course lesser risk associated with snow loads. 


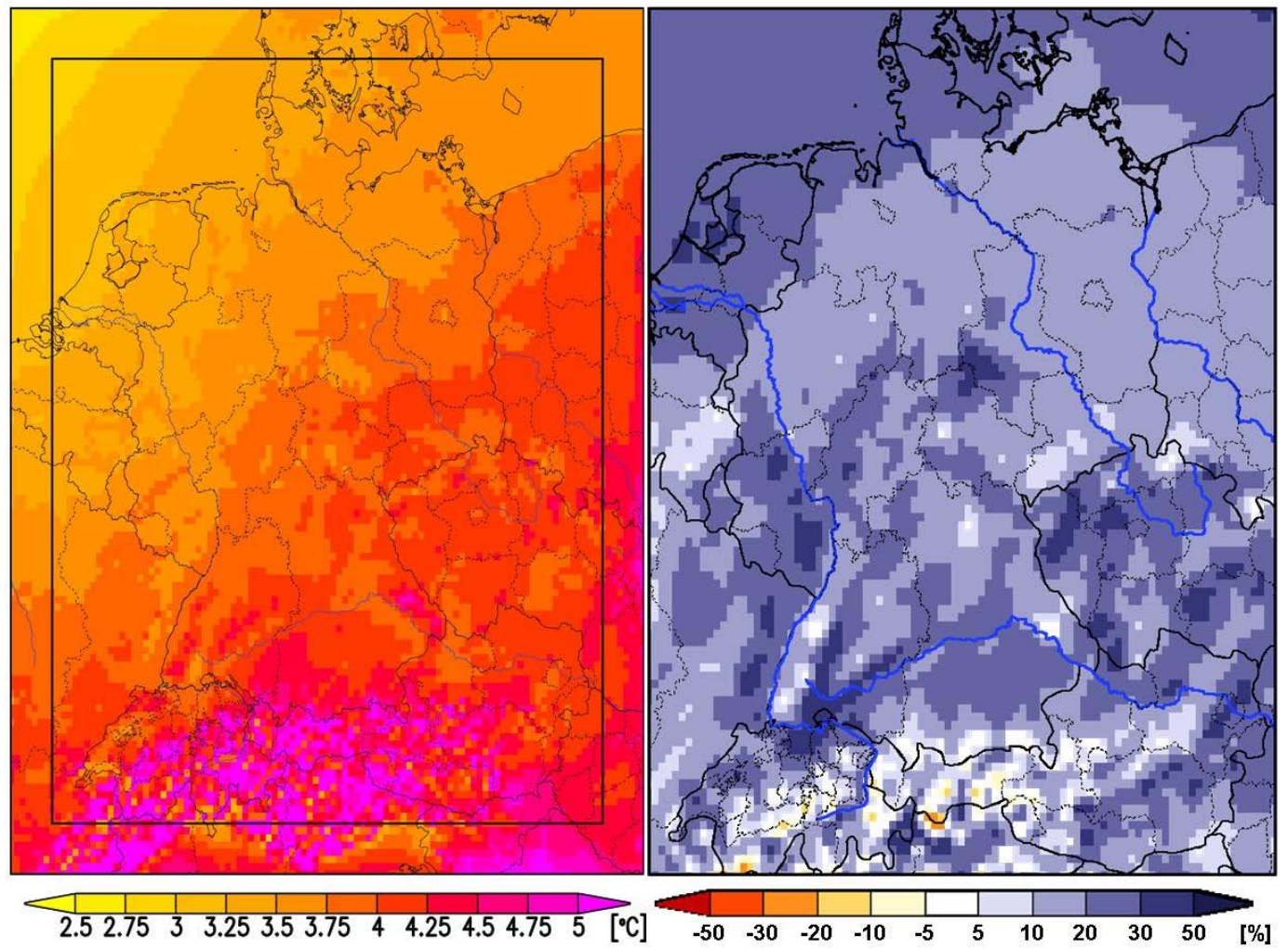

Fig. 6. REMO simulation of expected relative change of mean winter (December/January/February) - Temperature (left) and Precipitation (right) for A1 B scenario conditions between the simulation period (2071-2100) and the control run (1961-1990). Modified from MPI (2007).

1.5 An operational risk prediction system to identify critical snow loads

In Bavaria, a series of operational risk prediction and warning systems are operated by the Bavarian Environment Agency (LfU) to cover the areas of flooding, ozone, air pollution, weather extremes, avalanches and earthquakes (LfU 2008). However, no operational prediction system momentarily exists in order to monitor expected snow loads. Hence, the concept of such a system for this exact purpose is described as follows. As previously identified in this paper, the determining reasons for the potential collapse of a building refer back to the meteorological conditions, the development and continuity of an actual snow mass or better said the sudden increase in the snow load in combination with the roof-scale heterogeneity. In order to predict such risk, the following considerations must be taken into account: Firstly, the use of relevant meteorological data, mainly swe, from adjacent meteorological stations is not always necessarily representative or applicable for all roofs due to smallscale precipitation heterogeneity, drainage conditions, wind action and other location-specific effects and secondly, an assessment of the development of the snow load for any roof requires continuous observation. Consequently, an operational risk prediction system implies the installation of ap- propriate observation sensors recording actual snow loads on roofs. Attempts to measure the snow loads on roofs in Austria using a snow pillow device have already proved successful combining meteorological data and data from the snow pillow device (Sommer, W., personal communication, 2006). The snow pillow device in question is $1.5 \mathrm{~m}$ in length, bearing a weight of $200 \mathrm{~kg}$ (filled state), with a height of only a few $\mathrm{cm}$ being thereby small enough in that the distribution of snow on the roof should not be influenced when the snow load bears significant depths. Such technical equipment is rather cheap and installable on any flat roof capable of carrying this additional weight. In order to accurately predict the expected snow load, the development of the snow load on a specific roof can be predicted using the meteorological forecast over a period of 3 days. Therefore the current snow load together with the meteorological forecast results in the expected snow load. However, the question arises, as how to spatially interpolate the snow load related risk between the roofs equipped with such stations.

The German Weather Service (DWD) provides Bavaria with hourly snow model results from the operational snow model "Snow 3" with a resolution of $1 \mathrm{~km}$. The results include the snow water equivalent and amount of water released for an undisturbed ground snowpack (melt and rain). The snow model "Snow3" utilises an hourly "Lokalmodell" 
(LM) output (Adrian and Frühwald, 2002) to simulate the development of the snow cover for a $72 \mathrm{~h}$ period. The potential increase of the snow load over a 3 day buffer is sufficient to act as a warning in order to remove snow from critically effected roofs. This particular combination of using model output data together with the local swe observations on roofs could be implemented as follows: In all those simulation pixels where a sensor is installed, the difference between the observation of the sensor and model output for the respective cell can be derived. Sensor recordings exceeding the model output are thereby a signal that either the model underestimates swe or local re-distribution processes have increased roof load (this was pointed out earlier in that the ground swe is generally higher than roof loads). By computing this difference for all station locations, a dataset is provided which could be used to (a) regionalise this deviation for the area of the simulation domain, combine it with (b) the modelled regional ground swe, and then again combine the result with (c) the predicted evolution of swe from the predicted model runs. Point (a) is a scientific task, requiring the identification of the local effects enforcing the difference between observation and modelling and then involving the regionalisation of results. Point (b) delivers a distributed representation of the roof snow load for the simulated domain, which can be utilised later to identify any historically deemed dangerous developments. Point (c) represents a series of maps depicting the predicted increase of snow loads.

Despite the potential of utilising a risk prediction system, the local melt water re-distribution processes of a roof must also be considered. The monitoring of structures where sectors of unevenness exist or monitoring a small-scale water equivalent distribution on a roof (e.g., by using a radar sensor device) are promising techniques to assess certain zones of additional structural stress. However, these issues are technical and roof specific issues and go beyond the scope of this paper.

\section{Conclusion and outlook}

This paper evaluated the mass of the snow load on a roof and its probability of being the single factor responsible for the collapse of a roof. At the time of the catastrophic events occurring in Bavaria (January and February 2006), only moderate snow loads were recorded on the specified effected structures. In Germany, the designated snow load threshold for a certain roof type is defined by its geographical snow load zone and modified by its topographical elevation and roof pitch.

In analysing data from respective German DWD meteorological stations, it has become evident that a continuous snow cover over several months and temperatures frequently rallying around freezing point played a key role in marking the early winter of 2005/2006 as an exceptional one. These conditions probably caused significant local accumulation and re-distribution of the snow load on roofs. In Bad Reichenhall, this particular period lasted from 18 November 2005 until the event in question on 2 January 2006. The heavy snowfalls and the sudden increase of the snow load on that particular day may well have provided the trigger event which resulted in the collapse of the roof.

According to future climate predictions, both temperature and precipitation are expected to increase in winter. The predicted change is however characterised by a small scale heterogeneous pattern making an overall snow load risk trend difficult to predict. In general, higher temperatures will result in a reduction of snowfall and an increase in rainfall. Rain falling however on snow, can be stored within the snow pack resulting in an increase in the total snow load. The probability of long periods with continuous snow coverage will likewise decrease particularly in low areas. In higher areas above sea level however, temperatures will remain cold enough and the increasing precipitation will result in even higher snow loads thus increasing the respective risk. In all, the predicted increase in the variability of meteorological extremes may well lead to more frequent heavy snowfalls.

The optimal strategy for dealing with snow load risks in a changing climate is a process of monitoring and prediction.

An operational warning system capable of predicting critical snow load risks on roofs must keep all the relevant factors associated with it in mind. Regional swe modelling could provide required historical snow cover development incorporating intermediate thawing phases and durations of which, associated with the re-distribution of the snow load on roofs. The application of climate model results as an input for a snow model may well assist in providing a future prediction of what additional swe is to be expected. A nowadays feasible resolution of $1 \mathrm{~km}$ with a 3 days prediction time period is envisaged. Automatic roof monitoring stations consisting of a combination of meteorological sensors and a small snow pillow device is envisaged, thereby facilitating not only meteorological observations but also the monitoring and measurement of the actual snow load mass. The regionalisation of the observed swe at roof scale and the simulated swe in the modelling domain will require scientific effort in analysing the effect of the parameters which determine the deviations. In doing so, this scaling technique can be utilised to systematically produce regional maps of areas where critical snow loads are predicted.

Acknowledgements. Special acknowledgement must be paid to those who provided their help and assistance in the preparation of this paper. In particular, R. Weidinger, who processed the meteorological data, improved the figures and corrected the manuscript. Arousing discussions with M. Bernhardt, M. Prasch and W. Mauser (all Munich) proved most beneficial. Many thanks to two anonymous reviewers and to L. Duffy for making necessary language corrections. T. Reich (Berlin) provided valuable information regarding the German Weather Service's operational snow model. W. Sommer (Koblach/Austria) provided valuable technical information on the aspects of measuring snow loads on 
roofs. Finally, the Versicherungskammer Bayern initiated this particular investigation theme providing a scientific platform of discussion with a round of experts. Partial grants, with which this work was completed was provided by the GLOWA-Danube project (http://www.glowa-danube.de).

Edited by: M. Keiler, S. Fuchs, and T. Glade

Reviewed by: two anonymous referees

\section{References}

Adrian, G. and Frühwald, D.: Design der Modellkette GME/LM, promet, 27, 3/4, 106-110, 2002.

DIN, DIN 1055-5, Einwirkungen auf Tragwerke -Teil 5: Schnee und Eislasten, Deutsches Institut für Normung e.V., 2005.

DWD, Deutscher Wetterdienst, Klimadaten zu den Stationen Bad Reichenhall, Holzkirchen, Mühldorf/Inn, Fürstenzell, Offenbach, 2006.
IPCC, IPCC Fourth Assessment Report. Working group I: The Physical Science Basisof Climate Change http://ipcc-wg1.ucar. edu/wg1/wg1-report.html,last access: 9 January 2008.

LfU, Bavarian Environment Agency, http://www.lfu.bayern.de/, last access: 9 January 2008.

Maidment, D. R.: Handbook of Hydrology, McGraw-Hill, 1400 pp., 1993.

MPI,http://www.mpi-met.mpg.de/wissenschaft/ueberblick/ atmosphaere-im-erdsystem/regionale-klimamodellierung/ remo-uba/abbildungen.html, last access: 9 January 2008.

Müller-Westermeier, G.: Klimatologische Anmerkungen zu den Schneedecken im Bayerischen Wald im Februar 2006, DWD online, http://www.dwd.de/de/FundE/Klima/KLIS/prod/ spezial/regen/KlimatologischeAnmerkungen_Schneedecken_ Bayrischer_Wald_Februar_2006_2.pdf, 2006. 